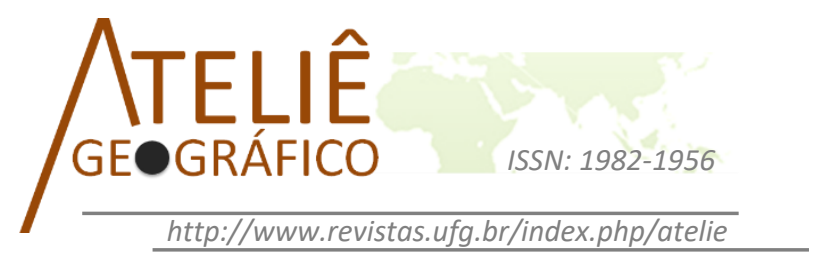

\title{
Matergrafia e patrimônio: Santuários Marianos como espaço simbólico e vetorial da Latinidade
}

\author{
Matergraphy and heritage: Marian Shrines like symbolic and \\ vector space of Latinity
}

Matergrafía y patrimonio: Santuarios Marianos como
espacio simbólico y vector de la Latinidad

Christian Dennys Monteiro de Oliveira

Universidade Federal do Ceará

cdennys@gmail.com

\begin{abstract}
Resumo
O artigo aborda a transformação histórica e metodológica dos estudos sobre santuários brasileiros, com base na invocação católica da Conceição Aparecida, em uma reflexão cultural sobre o espaço simbólico na América Latina. Considerando aspectos históricos, semióticos e institucionais muito expressivos para análise do patrimônio cultural no continente, o trabalho reconhece a emergência de uma rede de identificação do espaço religioso. Essa geografia de projeção cultural favorece a interpretação articulada de vetores simbólicos (nas festas, mídias e turismo), facilitando tanto a comparação de outras localidades (municípios-santuários), no Brasil e na América Latina, quanto a caracterização da estética teatral das devoções na construção do patrimônio continental. Sintetizando a verificações qualitativas feitas durante três anos de investigação sobre as estratégias de irradiação da devoção mariana, o estudo alcançou uma avaliação da força estética do patrimônio religioso como um desafio de valorização patrimonial da latinidade. E concluiu que o grande risco ao patrimônio cultural religioso está no crescimento das ideologias fundamentalistas, que buscam descredenciar a legitimidade da tradição Mariana e o sincretismo religioso e cultural na identidade continental.
\end{abstract}

Palavras-chave: Símbolo, Devoção Mariana, Santuário, Latinidade, Patrimônio Religioso.

\begin{abstract}
The present article approaches the transformation in the studies on Brazilian shrines based on the Catholic invocation of Our Lady of Conception Aparecida by means of a cultural reflection on Latin America's symbolic space. Considering expressive historical, semiotic and institutional aspects to the analysis of the continent's cultural
\end{abstract}


patrimony, this article acknowledges the emergence of an identification network of religious spaces. Culturally-projected Geography favours the articulate interpretation of symbolic vectors, such as festivities, media, and tourism, facilitating both the comparison between other localities, such as municipalities and shrines, in Brazil and Latin America, as well as the theatrical characterization of devotions in the construction of the continent's patrimony. Summarizing the qualitative verifications made along three years of investigation on the strategies of irradiating Marian devotion, this study has assessed the aesthetic strength of religious patrimony as a challenge to the appreciation of Latinity. This study arrives at the conclusion that the greatest risk to cultural religious patrimony lies in the growth of fundamentalist ideologies, which seek to discredit the legitimacy of the Marian tradition along with its cultural and religious syncretism and continental identity.

Keywords: Symbol, Marian Devotion, Shrine, Latinity, Religious Patrimony.

\section{Resumen}

El artículo desarrolla la transformación de los estudios sobre santuarios brasileños, con base en la invocación católica de la Conceição Aparecida, en una reflexión cultural sobre el espacio simbólico en América Latina. En cuanto a aspectos históricos, semióticos e institucionales muy expresivos para el análisis del patrimonio cultural en el continente, el trabajo reconoce la emergencia de una red de identificación del espacio religioso. Esta geografía de proyección cultural favorece la interpretación articulada de vectores simbólicos (en las fiestas, medios y turismo), facilitando tanto la comparación de otras localidades (municipios-santuarios), en Brasil y en América Latina, como la caracterización de la estética teatral de las devociones en Construcción del patrimonio continental. Sintetizando las verificaciones cualitativas realizadas durante tres años de investigación sobre las estrategias de irradiación de la devoción mariana, el estudio alcanzó una evaluación de la fuerza estética del patrimonio religioso como un desafío valoración patrimonial de la latinidad. Y concluyó que el gran riesgo al patrimonio cultural religioso se encuentra en el crecimiento de ideologías fundamentalistas, que buscan describir la legitimidad de la tradición mariana el sincretismo religioso y cultural en la identidad continental.

Palabras clave: Símbolo, Devoción Mariana, Santuario, Latinidad, Patrimonio Religioso.

\section{Introdução}

Penso e existo, logo estudo forja a máxima resposta de Gaston Bachelard (2008 [1931-1934]) a seu antecessor, René Descartes, autor do Penso, logo existo. Não nos vemos se quer a distância quilométrica desses e de muitos outros geniais pensadores do processo de desenvolvimento das teorias da ciência. Mas, por mero direito natural à Imaginação - pulsão tão delirante quanto ousada da mítica existência humana continuaria respondendo aos seletos pensadores: Estudo o espaço geográfico, logo, o simbolizo permanentemente.

A construção simbólica do espaço permitiu-nos identificar lugares seletivos, especialmente dotados de marcas e identificações diferenciadoras da condição banal. Cidades, vales, cadeias montanhosas, áreas de proteção, florestas, zonas comerciais, 
bairros ou faixas litorâneas, enfim, toda uma denominação locacional pode constituir uma espécie de "folha em branco", um pressuposto gráfico genérico sobre o qual dá-se um desenho intencional. E o desenho, humanisticamente dotado do artifício de refazer a natureza em cultura é o ato criativo de emergir significados; ou em metáfora semelhante, comunicar aos navegantes a ilha de gelo submersa pela ponta emersa do iceberg. Em que medida cada lugar simbólico que estudamos pela condição redesenhada de "santuário" equivale a esse iceberg significante? E em termos de delimitação territorial identificadora, como um município pode promover-se a santuário pós-moderno, agregando tradições e inovações em sua trama de forças vetoriais?

Logo de início, devemos esclarecer que a ideia de "força vetorial" arregimenta uma metáfora da Física Moderna na composição teatral dos eventos que caracterizam a funcionalidade dos lugares. Nossa aceitação do termo "vetor simbólico" adveio de uma leitura semiótica dos espetáculos cênicos, proporcionada pelo crítico e teatrólogo Patrice Pavis (2008), quando propôs uma tríade condicionante na análise dos eventos teatrais: tempo, espaço e ação, e sua interdependência mobilizadora (no cronotopos, inspirado pela teoria contextual de M. Bakhtin) que o autor nomeia por vetores do espaço em movimento.

A resposta tende ao mecanicismo quanto consideramos o ato batismal de nomear (diferenciando) cada um daqueles "genéricos" espaços citados, além de todos os demais que poderíamos imaginar, como exemplo preliminarmente acessível de espaço geográfico. Cidades capitais, cidades históricas, cidades militares, cidades perdidas. Aqui já se conecta um outro sentido (específico) à anterior generalização. Assim como vales pastoris, pantanosos, planejados ou de combates, também podem qualificar uma vivência de significados; mais ou menos representativos das expectativas humanas que justificam (selecionam) tal nomeação. Temos desta feita a fundação do lugar no caminho de uma especificação. Um cenário que (re) memoriza uma cena, ou um conjunto de cenas que melhor marcaram tal cenário.

É neste rumo que o espaço encontra o movimento do tempo (geológico, geomorfológico e antrópico, portanto, cultural) se libertando dos determinismos vinculantes da fixidez, sempre mais reconfortante para os desenhos gerais, e assumindo o parâmetro contemporâneo da fluidez específica. Que cidades, que vales, que eventos elementares configuram uma celebração teatral do geográfico externo em símbolo geográfico? Ou, como preferimos indagar, na veiculação desse conjunto de estudos que conduzimos aqui, como a Geografia, em sua natureza cultural, se torna Matergrafia, adquire dimensão teatral e se decodifica em uma patrimonialidade?

O ponto de partida é, com todas as dúvidas que o cartesianismo renova no jeito de pensar e sentir bachelardiano, o alargamento do conceito de "santuário", de espaço simbólico e vetorial, motivador de uma diversidade de eventos acionados pela força da leitura religiosa do mundo. O lugar - espaço específico, que bem ou medianamente "conhecemos" por atribuição de significados - correlaciona-se permanentemente com os espaços do desconhecimento. Luz e sombra, som e silêncio, sabor e sensação, toque e vontade, sacro e profano associam-se para mover o espaço/tempo da Terra, por desenho 
(gráfico e imaginário), correspondem a minha/a vossa/a nossa busca de significados. Um santuário pode ser, portanto, essa profusão de sentidos ambíguos, conectados antes pela projeção mítica que os sistemas de comunicação religiosa bem acolhem. E com base em abordagens filosóficas mais abertas à subjetividade interativa - particularmente a fenomenologia, existencial e hermenêutica - que podemos tentar essa "acolhida" no processo de aprendizagem científica. Seguindo geógrafos/as humanistas - como Eric Dardel, Edward Relph, Yi-Fu-Tuan, David Lowenthal, Giuliana Andreotti, Anne Buttmer e Lívia de Oliveira - em Geografias Marginais, conforme sugestiva leitura de Kozel (2015).

Os denominados santuários - originários do campo religioso - são, de fato, lugares simbólicos representativos dos espaços vividos e das vivências em sua temporalidade cênica (OLIVEIRA, 2012). Iremos, por motivação meramente didática, a partir das formulações fixas de constituição, religiosa tradicional, tecnológica urbanometropolitana, paisagística ecológica ou natural, para nos aproximarmos de sua cinética criativa. Artisticamente, a constituição fluida dos santuários como "manifestação", como festa de "coroação", forja um casamento cronotópico de espaço com tempo, e vice-versa. Nas palavras de Ferrara (2008), trata-se de vislumbrar os condicionantes ativos tempo/espaço como símbolo, capaz de reunir, de comunicar, de aproximar um habitat de uma eventualidade.

Nas primeiras décadas do XX, Bakhtin procurou enfrentar esse desafio, e com acentuada sagacidade, entreviu o futuro que já começava a impor a necessidade de atentar para a natureza do modo como o tempo era o arquiteto do cotidiano. Como resposta possível a esse desafio, Bakhtin criou os conceitos de polifonia e diálogo, que recuperam a longa duração na construção de mentalidades da cultura e o espaço semiótico de manifestações que se expandem, (FERRARA, 2008, p. 101)

Reconhecemos então uma interface geográfico/semiótica dos santuários, pois sua significação, como objeto científico, desafia novas maneiras de ordenamento tempoespaço. Adiante, no encerramento desta breve jornada, veremos como a matergrafia dos santuários nos promove a readaptar polifonia e diálogo, em um conjunto de pesquisas qualitativas sobre a comunicação patrimonial voltadas para o entendimento do espaço religioso. Antes, porém, o recorrente conceito de "sagrado", em sua organicidade, precisa ser melhor delimitado.

\section{Problematização}

Não existe, portanto, santuários forjados na exclusividade funcional de um único papel sagrado. O que o sistema de interpretação discricionário de Mircea Eliade adotou, para compreensão do homem mítico pré-moderno, separa didaticamente um centro sagrado (mono identificado) de vários arredores "profanos" (mult identificados). Tal 
separação não só pode como deve favorecer o instante fotográfico de um filme mais dinâmico. A sacralidade, como "umbigo" ou "axis" (eixo) do mundo, somente emerge como reverência ritual das celebrações se, e tão somente se, todos os momentos e lugares não rituais cooperarem em sua profanidade. Expressão essa bem melhor compreendida no sentido de "preparação" do que de "negação" ou "ofensa"; exatamente para dar viabilidade à realização daquele projeto sagrado.

Tudo isso certamente será válido ao ignorarmos as sacralidades marginais, aquelas não hegemônicas ou subordinadas. Algo costumeiramente feito quando se reduz "sagrado" aos clássicos sistemas religiosos monoteístas: judaísmo, cristianismo, islamismo (GIL FILHO, 2008). As sacralidades do universo Profano, proporcionam também tempos/espaços especiais, relativamente complexos e merecedores do reposicionamento do axis mundi. Especialmente em sociedades modernas que incorporaram múltiplas tradições e agregaram novos ritos e mitos em suas composições religiosas. Exatamente por essas novas "composições" que passamos a observar a força difusora de santuários em modelos não tradicionais no espaço ritual, urbano e natural, para além da referente constituição agropastoril, tão marcante da formação colonial brasileira. A pós-colonização vivida no limiar do século XXI, como sabemos, por investigação e vivência social, ganhou novas e diversificadas tessituras do campo religioso específico; ou mesmo do campo secular, adensado por crises sobrepostas e múltiplos sistemas de informação, cujo processo imediatamente resultante tende a fazer emergir novas religiosidades. Seja na política, no direito, na cultura artística, na ética da ciência, da filosofia e da tecnologia.

Chegamos a esse alargamento do campo religioso, por intermédio de elementos simbólicos desenhados no espaço patrimonial. Tais elementos nos despertam uma possibilidade ímpar na pesquisa em geografia cultural, que ora gostaríamos de amadurecer, promovendo-os como fonte de novas investigações para projetos de estudo em parcerias. Os santuários marianos, no catolicismo popular, esboçam uma dinâmica de resposta à tradição judaica. Não se trata mais de refazer uma atualização do nomadismo semítico ao sedentarismo de Israel, modernamente consagrado na esteira das conquistas dos Direitos Humanos Universais (SANTOS, 2014). Tal direcionamento veio sendo alimentado pelo mito daquele "povo escolhido" e da busca da "terra prometida". Por seu intermédio, promovia-se a transformação de uma aliança móvel (instável) em no grande templo imóvel (estável), localizado em Jerusalém.

Trata-se de recompor toda uma saga mitológica, na interpretação de que o cristianismo se ergueu em dois pilares urbanos: Jerusalém e a Outra cidade conquistada como "santa": Roma ou suas congêneres terrestres. Ambas conectam lugares e povos diversos, na desafiadora ideia de que as arcas da aliança são múltiplas, humanas e planetárias. Assim, se o judaísmo forjou ao sistema religioso ocidental uma "herança", um legado paterno primário, quando pensamos nos traços greco-romanos do cristianismo devemos visualizar a contrapartida materna. Tida como "secundária", quando nos limitamos a pensar esse Paganismo síntese de infinitos paganismos étnicos/regionais, 
forjados em quase 1600 anos. A contar da conversão de Constantino, de Imperador a Papa de Roma, como um processo inferior na sedimentação cristã.

A proposta aqui é diametralmente inversa. Considerando que o empreendimento continental, que se convencionou a chamar de "América Latina" - seja em sua majoritária dominação ibérica, seja na contestação franco-holandesa ou anglo-saxã - vivenciou de fato a inversão da matriz prioritariamente pagã sempre alicerçada em múltiplos lugares santos. Aqui o vínculo paterno com a velha Jerusalém, nunca se tornou relevante. Embora, devamos reconsiderar essa distância (relativamente menor) quando se examina os interesses internacionais renovados do protestantismo, especialmente na perspectiva do imaginário neopentecostal. Lembramos, em particular, do uso litúrgico e discursivo sobre os episódios heroicos do Velho Testamento e as formas de representação cinematográfica e arquitetônica da Igreja Universal do Reio de Deus (IURD), com megaempreendimentos turísticos como o Templo de Salomão, em São Paulo (SP).

Uma complexa matriz profana/pagã do cristianismo permite-nos, então, encontrar nos modelos mais variados de santuários a forma simbólica de construção "latina" redesenhada como continente americano. Normalmente, tal matriz é pensada em sua versão defensiva, correspondendo à condição exclusiva de vítima do processo de colonização. As tradições indígenas e afrodescendentes, além das relevantes minorias étnicas, são desassociadas - em uma espécie de apartheid confortável à intelectualidade universitária - de responsabilidade, frente a lógica do catolicismo popular. Acontece que não foi assim com os gregos, e não será com a interpretação aberta de qualquer povo incluído em um pedaço da América. Neste extremo ocidente (interessante assim pensar), o foco crescente nos bens imateriais constrói seu reconhecimento sociocultural à luz de uma mescla infinita de fontes culturais. Por desdobramento o espaço geográfico do campo religioso, precisa adquirir especificidades assentada nesta lógica matricial. Aqui a Geografia se recria em Matergrafia, a fim de expandir seu conhecimento científico prévio em linguagem de aproximação de distintos saberes. A Matergrafia é uma forma de dizer que geografias cultural e da religião possuem um expressivo "dom" de produção de bens e serviços, enraizado na diversidade da experiência dos povos (CLAVAL, 2008). Especialmente quando tais povos não dispõem de um histórico de conquistas, capaz de lhes proporcionar empoderamento mais efetivo do que o reconhecimento de seu direito à existência. Muito pouco para tamanha explosão de demandas sociais. É o caso das realidades socioambientais que tipificamos como América Latina; e para qual este ensaio pretende conduzir exemplos ou modelos de santuários marianos.

Teremos como referência de exposição, inicialmente, os três modelos de redes devocionais em escala nacional, partindo da realidade brasileira, com santuários de diferentes portes: Aparecida, no interior de São Paulo, completado por sua área territorial de irradiação diocesana; Belém, capital do Pará, projetada em seu grande festival regional; e Juazeiro do Norte, no sul do Ceará, cultivado em sua tradição de resistência peregrina.

Buscaremos demonstrar, primeira seção, equivalências latino- americanas, com marcas nacionais, festivas ou populares, capazes de traduzir o modelo "tradicional" 
santuário; e simultaneamente apontar as forças predominantes na dinâmica dos vetores simbólicos de irradiação devocional.

$\mathrm{Na}$ segunda seção, trabalharemos a exposição caracterizadora dessas forças vetoriais, em sua natureza comunicacional ou, como preferimos reconhecê-las, "geoeducacional". Isto por que é possível reaprender as formas de conhecimento dos espaços geográficos no jogo metafórico entre três níveis hierárquicos de valorização dos bens imateriais. Inicialmente os mais profundos, ou "mítico-religiosos" que projetam nossos rituais e atualizam as práticas religiosas em estéticas de carnavalização. Sequencialmente, por via intermediária, vem aqueles níveis de intercâmbio, que traduzem em linguagens ambientais as formas da natureza. Os denominamos vetores "midiáticoecossistêmicos" e correspondem a estéticas de publicidade. E no plano mais superficial, as últimas forças vetoriais, "político-nômades" ou "político-turísticas", respondem pelas demais esferas que modelam a externalidade terrestre, como planeta cultural. E nesse sentido forma uma estética de mobilidade e mudança permanente.

Simplificando, para compreender tais forças como modeladoras dos santuários em um recorte espacial mensurável - chamado aqui de município-santuário renomearemos os vetores conforme a sua principal resultante. $\mathrm{O}$ primeiro manifesta-se por Ritualização; o segundo por Midiatização e o terceiro por Visitação. Desse modo, a festividade "ritualizante", a Publicidade "midiatizante" e o Turismo "visitante", representam, neste estudo, três energias comunicacionais (e geoeducacionais) de consolidação do espaço simbólico em Municípios- Santuários. Os exemplos aqui emergem diretamente dos estudos realizados como o grupo de municípios devotados à invocação de Conceição Aparecida, cuja hierarquia diocesana transformou-se em santuários regionais, desafiando assim a ação, ora colaborativa ora competitiva dos três vetores.

No encerramento do trabalho, vem o momento de se debruçar diretamente na concepção de patrimônio religioso ou patrimonialidade emergente desse desenho devocional mariano. Exatamente porque, à revelia dos cuidados da laicidade e do domínio público da cultura religiosa, uma confluência de polêmicas faz transbordar o reconhecimento de que uma "questão religiosa" republicana está longe de ser resolvida. Justamente aquela que deveria traduzir em patrimônio cultural os múltiplos bens do catolicismo popular; porém "reduz" (e não traduz) em um complexo jogo de tensões entre práticas litúrgicas crescentes e resistentes. Sejam elas cristãs, não cristãs ou antirreligiosas. Mas cuja resultante principal é a emergência de processos mais ou menos fundamentalistas; incluindo entre eles a leitura da própria devoção mariana como uma espécie de contrarreforma católica.

E, neste sentido, valerá demasiadamente a pena demonstrar que a continuidade da investigação sobre o papel das padroeiras marianas no universo de países do continente - incluindo as chamadas nacionalidades anglo-saxãs - coincide com uma reorientação da política cultural internacional. Seja qual for o papel desempenhado pelo patrimônio religioso nas nações americanas, as transformações confessionais (no interior ou fora do 
cristianismo) e o peso da escolaridade moderna na formação social da juventude, não se pode mais ignorar o trânsito entre a devoção mariana e a consciência das vulnerabilidades da natureza terrestre. Exatamente por essa razão, a leitura da geografia como "matergrafia" redimensiona o existir no espaço como estudar seus fluxos simbólicos. Ali, nos santuários, onde reconhecemos o nascedouro matergráfico, também percebemos as tensões patrimoniais.

\section{Santuários Marianos Brasileiros: três modelos vetoriais}

A leitura da religiosidade popular a partir da devoção a representação de Santa Maria consolida um movimento de diálogo indispensável ao fortalecimento das tradições cristãs, em contexto de secularização geral da sociedade. Espacialmente, no âmbito latinoamericano e brasileiro, isso se traduz imediatamente multiplicação ilimitada de invocações marianas. Em outras palavras, em formas de moldar a imagem de Maria, Mãe de Deus, pela plasticidade de signos motivacionais capazes de espelhar Marias, tão diversificadas quantos as infinitas Filhas de Deus. Ou seja, a mais feminina das expressões divinas do cristianismo é irradiadora natural da mais ilimitada tendência a multiplicidade de representações.

As representações marianas, nos contextos locais e históricos, podem ser compreendidas como mera adequação didática da negociação entre a expansão católica (mesmo pós-colonial) e a submissão de fiéis, "passivamente" dependentes de uma imagem humana comprometida com uma funcionalidade material mais concreta ou imediata. Senhora das Dores (para atenuá-las por nós), Senhora do Auxílio ou Socorro (para nos ajudar), Senhora da Esperança (para nos reanimar), Senhora das Graças (para nos conceder), entre tantas Senhoras. Sem falar dos Santos e Santas, tão ou mais comprometidos em fazer com que essa multiplicação de Senhoras expresse um coletivo de intenções; quando não compensações de um ou outro auxiliar de Deus Pai, que falhou ou não foi devidamente compreendido. Localidades reconhecidas como centros de devoção mariana, a partir da tradicional invocação de Conceição Aparecida, tendem a manter esse mesmo princípio: uma ideia de que a presença da virgem, em imaculada concepção, se faz presente para nos demonstrar que a fartura e a fertilidade são possíveis; ainda que em um mundo de ostensiva escassez.

Este trabalho considera oportuna a leitura integrada de 37 Santuários Marianos, criados pela associação de invocações diretas da Mãe de Deus no Cristianismo católico, como a Imaculada Concepção ou Conceição (mais utilizada). Além de compreender uma dessas invocações especialmente - a da virgem Aparecida - como aquela capaz de sintetizar essa ultrapassagem dos limites naturais ou sociais na divina intervenção; tão visível (aparecida) como miraculosa (gravidez ou nascimento de uma virgem). Isto porque, além do Santuário principal (o 38\%), situado na cidade de Aparecida (distante 174 $\mathrm{km}$ da capital paulista), os santuários menores ou mais regionalizados projetam as modulações das formas de agregar uma devoção familiar, comunitária ou local em meios de expansão da representação religiosa de tais localidades. 
A devoção mariana contempla a modulação local mais substantiva e concreta, da pedagogia da fé cristã composta de grande apelo abstrato. A Santíssima Trindade, complexo da mística católica romana que "explica" a correlação entre as figuras de Deus Pai, Filho Encarnado de Deus e Espírito Santo abre espaço intelectual para uma ampla Teologia do sistema Religioso que referendou o que denominamos Mundo Ocidental. Mas tal complexo deixa escapar as múltiplas influências adaptativas de povos periféricos ("bárbaros", "aborígenes", "indígenas" e "negros da terra"), que tanto dependiam das divindades regionais e locais para negociar os caminhos da aprendizagem significativa dessa fé tão abstrata e distante. A sensibilidade visual e tátil, canalizada pelo exercício pedagógico figurativo dos ícones cristãos, via imagens substantivas da mediação Divindade/Humanidade nos santos, promoveram a passagem da "explicação" em "implicação". Implicar é comprometer, envolver, dotar pertencimento nas obrigações quando aparentemente só se enxerga propriedade físico-material (RUIZ, 2004).

Lembra-nos Murad (2016, p. 54), em seu estudo sobre a teologia da imagem na iconografia da Mãe de Deus, que após uma conturbada história de negação e afirmação do ícone religioso mariano no sistema de construção do conteúdo da fé,

A rigor não se pintam ícones, e sim se escrevem. Seria como a Sagrada escritura plástica, em imagem. Daí o termo iconografia (que significa escritura de ícones) e iconógrafo (o escritor de ícones). É uma vocação apreciada na igreja oriental e que implica séria responsabilidade e preparação espiritual adequada.

A transposição desse processo para o Ocidente, precisou encontrar sua conturbada fase se pulsação histórica no limiar da modernidade renascentista reordenada pelo esteticismo barroco. A escrituração bidimensional ganhou maior significação nos modelos tridimensionais dos santos, santas e santas Marias, que se projetaram dos estandartes das procissões e caravelas para ganhar formas de estátuas, caseiras ou institucionais. Nos santuários que tomamos por modelos marianos, na escala nacional Aparecida (SP), Nazaré (PA) e Dores (CE) - expressam esse momento de conquista e resiliência de um Brasil e uma América submetidos à modernização das formas de escriturar esse ícone cristão.

Um exercício vetorial de construção simbólica, da integração de diferentes lugares sacro-profanos, demanda a seleção de critérios integradores. Consideramos "sacro-profanas", localidades fixas ou eventuais (festivas) que representam a confluência de interesses religiosos na dialética de aproximação/afastamento dos valores mundanos. Assim, ao contrário das convencionais abordagens dicotômicas - dispostas a correlacionar diretamente o religioso com o "sagrado" X um não religioso manifesto com o "profano" - preferimos advogar a perspectiva de resposta tática das vivências marginalizadas reconhecidas Certeau (1990, p. 47), opondo a tática a estratégia (sagrada): "Ao contrário, pelo fato de seu não-lugar, a tática depende do tempo, vigiando para "captar no voo" possibilidades de ganho. O que ela ganha não o guarda. Tem constantemente que jogar com os acontecimentos para transformar em ocasiões. ” 
Tática é, existencialmente, a lógica vetorial que permitiu-nos tratar as escalas nacional/regional e reticular em movimento, como meios espaciais associativos, mas onde e como uma expressiva devoção mariana consolida um território de cultura plural? Estando em curso projetos de investigação sobre irradiação devocional visando demonstrar a desigual abrangência da invocação da Imaculada Conceição Aparecida, em escala nacional, fomos ao encontro de duas outras formas marianas capazes de representar as outras duas escalas. Assim, resumidamente, chegamos ao seguinte quadro síntese da projeção brasileira dos três modelos (Figura 1), e a partir deles, abrimos caminhos para compreender a potencialidade da formação tempo-espacial e simbólica do que será tratado na seção seguinte: os municípios-santuários .

A irradiação devocional encontra-se na base da mundialização do cristianismo. Sua marca elementar de sustentação aparece no exercício teológico de "evangelização"; ou em termos proféticos, de anunciação do novo testamento de Cristo, por múltiplas linguagens ou formas transmissão de sua mensagem aos diversos povos da terra. Os templos especialmente erigidos como "torres dessa transmissão" tendem a propagar em escalas ampliada tal "boa nova" (evangelho), para além dos limites paroquias da Igreja. O resultado dessa rede transmissora, nos domínios contemporâneos da espacialidade eclesial (dioceses, províncias e regiões episcopais) é projetar-se em níveis regionais de escala nacional. Daí pensarmos nos clássicos agrupamentos dos territórios socioeconômicos brasileiros (Centro-Sul, Amazônia e Nordeste Sertanejo) como uma correspondente demarcação aos três vetores simbólicos, com os quais identificamos a base empírica de nossos estudos: os municípios-santuários.

Tendo em vista um maior desenvolvimento, até aqui, dos registros sobre os vetores da rede devocional de 38 municípios promovidos a santuários de N.S. da Conceição (vide a sistematização dos mesmos no site do projeto <http://www.santuario.ufc.br/mariana/>), tornou-se possível a identificação de uma consistente dinâmica associativa/competitiva dos três vetores.

Basicamente, foram constatadas duas tendências predominantes na maneira de compreender o uso dos vetores simbólicos para promover a irradiação dessa devoção mariana em seu território de influência (SANTOS, 2006). A primeira, correspondendo ao projeto espelhado e inspirado no Santuário "padrão", em Aparecida (SP), associando as demais forças vetoriais, a partir do vetor mais representativos das negociações cívicorepublicanas: o político-turístico, responsável pelo ordenamento da visitação (devocional ou cultural). Sendo municípios de pequeno porte populacional, pois na tabela demográfica que ordenamos, Ourinhos (SP) com seus 111 mil habitantes, indica o limite de porte máximo no qual esse equilíbrio vetorial se manifesta. O mapa da Figura 2, inicialmente, identifica tais municípios, mostrando sua concentração na escala supra-regional, com predominância dos estados do Centro-Sul do Brasil. 
Quadro 01: Três Modelos de Santuários e seus Vetores de irradiação

\begin{tabular}{|c|c|c|c|}
\hline MODELOS & ESCALAS & $\begin{array}{c}\text { VETORES } \\
\text { SIMBÓLICOS } \\
\text { MAIS } \\
\text { RELEVANTES } \\
\end{array}$ & $\begin{array}{l}\text { ESPACIALIDADE } \\
\text { DEVOCIONAL }\end{array}$ \\
\hline tion & $\begin{array}{c}\text { Supra } \\
\text { Regional } \\
\text { do Centro- } \\
\text { Sul } \\
\text { Brasileiro }\end{array}$ & $\begin{array}{l}\text { Político-Turístico } \\
\text { (de Visitação) em } \\
\text { razão do } \\
\text { reprodução em } \\
\text { quantidades de } \\
\text { santuários (38) e } \\
\text { paróquias (+ de } \\
\text { mil) }\end{array}$ & $\begin{array}{c}38 \text { Municípios- } \\
\text { Santuários. } \\
\text { Espalhados } \\
\text { nacionalmente, com } \\
\text { maior concentração em } \\
\text { SP; MG \& Região Sul } \\
\text { do Brasil }\end{array}$ \\
\hline Nazaré de Belém & $\begin{array}{c}\text { Macro } \\
\text { Regional } \\
\text { da } \\
\text { Amazônia } \\
\text { Brasileira }\end{array}$ & $\begin{array}{l}\text { Midiático- } \\
\text { Ecossistêmico (de } \\
\text { Publicidade) em } \\
\text { razão da força de } \\
\text { difusão } \\
\text { patrimonial, em } \\
\text { registros materiais } \\
\text { e imateriais }\end{array}$ & $\begin{array}{l}27 \text { Festas-Capitais. } \\
\text { influenciadas pelo } \\
\text { Círio de Nazaré, mas } \\
\text { também reinventadas } \\
\text { em outros santos e }\end{array}$ \\
\hline Dores de Juazeiro do Norte & $\begin{array}{c}\text { Micro } \\
\text { Regional } \\
\text { do } \\
\text { Nordeste } \\
\text { Sertanejo } \\
\text { Brasileiro }\end{array}$ & $\begin{array}{l}\text { Mítico-Religioso } \\
\text { (de Celebração) em } \\
\text { razão das histórias } \\
\text { de conflito e } \\
\text { resistência à } \\
\text { conformação das } \\
\text { tradições no } \\
\text { catolicismo } \\
\text { popular }\end{array}$ & $\begin{array}{l}35 \text { Representações da } \\
\text { Latinidade } \\
\text { Americana. } \\
\text { Considerando a } \\
\text { densidade dos } \\
\text { conflitos no âmbito do } \\
\text { patrimônio religioso } \\
\text { continental. }\end{array}$ \\
\hline
\end{tabular}

Fonte: Elaboração do autor (2017).

Daí em diante, encaminhamos a leitura do agrupamento de informações advindas de duas fontes acumuladas no decorrer da pesquisa. De um lado a visita aos municípios do estado de São Paulo, no decorrer das atividades de campo realizadas, sempre nos segundos semestres de 2014, 2015, 2016. No total, foram nove municípios visitados e observados em suas estruturas para festividade religiosa e recepção turística de devotos e romeiros. Além de Aparecida, foram eles: Ourinhos, Ribeirão Preto, Bauru, Sorocaba, Jundiaí, Itapetininga, Tambaú, Ribeirão Preto. E em outros estados do país, aproveitando oportunidades de viagem não exclusivamente ligada à pesquisa, visitamos também os santuários à invocação de Conceição/Aparecida, em Belo Horizonte (Minas Gerais), Florianópolis (Santa Catarina), São Luís (Maranhão) e os municípios de Pedra de Fogo e João Pessoa (Paraíba). 

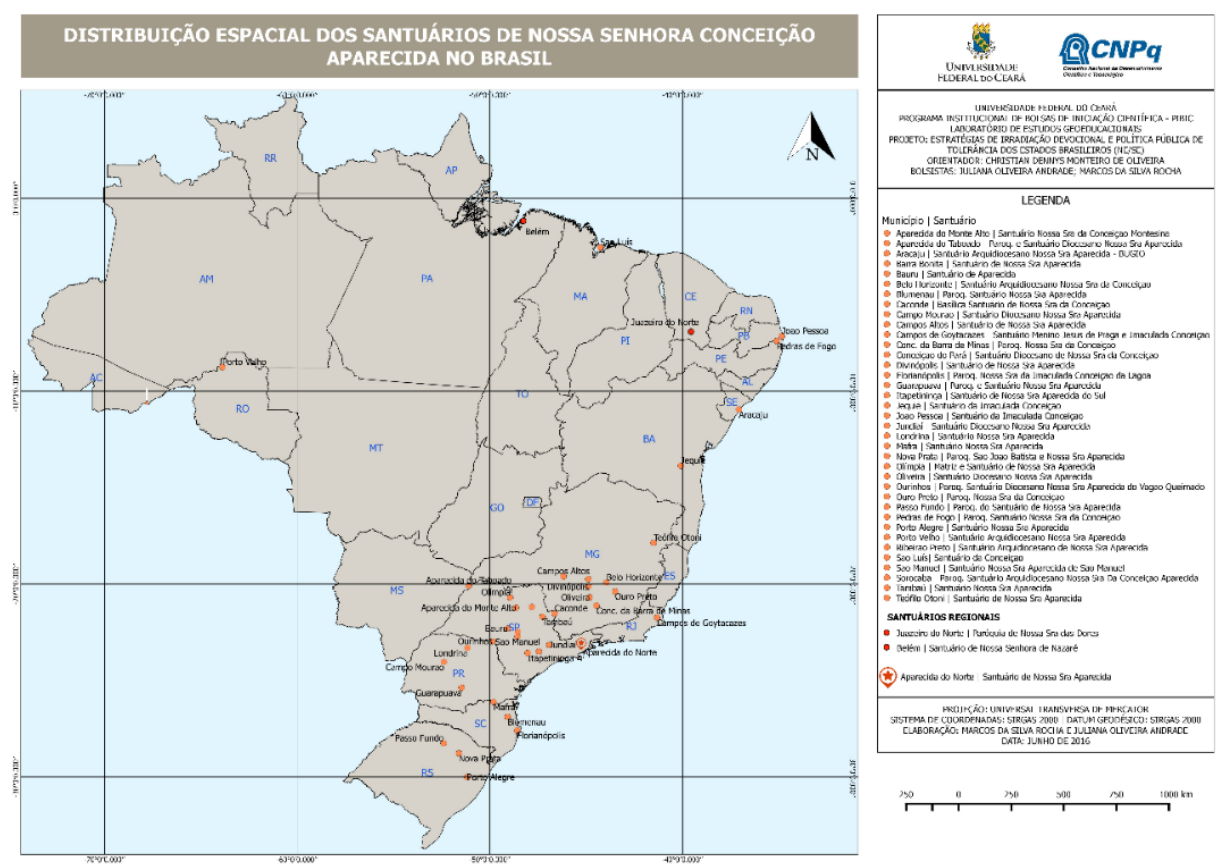

Figura 01: Santuários de Invocação a N. S. da Conceição no território brasileiro Fonte: Acervo do LEGES (2016).

Tal predomínio de capitais, completando o levantamento em 14 cidades visitadas, permitiu antever a segunda tendência, cuja caracterização ficou melhor delineada no levantamento que cruzou informações secundárias, provenientes de fontes digitais. $\mathrm{O}$ Quadro 3 relaciona os principais itens que consideramos para analisar e classificar tais fontes. Já a Figura 3 traduz em síntese o resultado dessa classificação: indica que a segunda tendência representa a maior rivalidade entre a os vetores simbólicos, associados a processos de configuração de patrimônios religiosos mais semelhantes a dois outros santuários marianos marcantes do Norte e Nordeste do Brasil. Ora emerge o predomínio midiático-ecossistêmica, similar ao processo que decodificamos no Círio de Nazaré, em Belém (Pará); ora se manifesta a liderança de vetor mítico-religioso, como em Juazeiro do Norte (Ceará). Ambos representativos valores sincréticos, relativamente mais tensos e profundo no desenho do catolicismo popular, muito embora manifestos em cidades bem maiores do que Aparecida. Daí a leitura "descendente" (não harmoniosa) do processo vetorial. 
Quadro 02: Itens pesquisados na formação do Banco de Dados.

\begin{tabular}{|c|c|}
\hline $\begin{array}{c}\text { VETOR SIMBÓLICO } \\
\text { ANALISADO }\end{array}$ & \multicolumn{1}{|c|}{ ITEM ASSOCIADO AO BANCO DE DADOS } \\
$\begin{array}{c}\text { Político-Turístico } \\
\text { (Devotos em visitação) }\end{array}$ & $\begin{array}{l}\text { Notícias e informações municipais (IBGE) } \\
\text { Programação de Festas cívicas } \\
\text { População/Renda per capta municipal } \\
\text { Empresas de serviços turísticos e entretenimento }\end{array}$ \\
\hline $\begin{array}{c}\text { Midiático-Ecossistêmico } \\
\text { (Cerimônias publicitárias em } \\
\text { midiatização) }\end{array}$ & $\begin{array}{l}\text { Notícias e informações do cotidiano social e ambiental } \\
\text { Festivais temáticos nas cidades ou distritos } \\
\text { Trabalhos Científicos do lugar ou região }\end{array}$ \\
\hline $\begin{array}{c}\text { Mético-Religioso } \\
\text { Meios de comunicação locais }\end{array}$ \\
\hline (Rituais em carnavalização) & $\begin{array}{l}\text { Notícias e informações de eventos religiosos } \\
\text { Imagens das Festas do/a Padroeiro/a } \\
\text { Site do Santuário }\end{array}$ \\
\hline & $\begin{array}{l}\text { Outras Religiões/Confissões não católicas em destaque } \\
\text { Vídeos das festividades no período da festa à N.S Conceição }\end{array}$ \\
\hline
\end{tabular}

Fonte: Elaboração do autor (2016).

A correlação desses 13 itens que completam o nosso banco de dados para os municípios-santuários foi elaborada considerando também a ausência de informações (lacunas de fontes), principalmente em localidades com menor porte econômico-regional e demográfico. O que reforça a condição de "colaboração" dos vetores em localidades até 100 mil habitantes. Nesses casos, a visita de campo em 14 das 38 localidades, proporcionou um exercício de reforço a observação da estrutura urbana, eclesial e estético/administrativa herdada do processo de consolidação do santuário no tecido municipal. O intuito não foi, portanto, observar o evento devocional para dimensioná-lo em seus impactos culturais na cidade, bairro ou distrito. Mas tão somente constatar a diversidades de formas paisagísticas inclusivas, seja do lugar "santuário" no espaço "município"; ou inversamente, por um jogo de representações simbólicas, o lugar município no espaço santuário.

Inversão que projeta e alimenta o parâmetro do modelo geográfico de Aparecida, ao expressar como o santuário nasce em uma periferia municipal (Guaratinguetá), cria a identidade local até tornar-se referência devocional (autonomia de Aparecida); e na monumentalidade de sua construção espetacular, recria toda espacialidade de serviços no interior do próprio santuário (Complexo metropolitano da Basílica Nova.). As fotos de Pedra de Fogo (na Paraíba), de Ribeirão Preto e Sorocaba (São Paulo) - Figura 4 encaminham sinais de projeção dessas "etapas aparecidenses" na configuração do patrimônio emergente nesses municípios. Cabe pensar, adiante, quais limites da representação pública desses santuários são capazes de articular a especificidade religiosa das comunidades cristãs ao acesso cultural não excludente da diversidade de grupos não católicos. Lidamos, dessa maneira, a partir de agora, com o desafio teórico da inversão vetorial das forças de irradiação simbólica, promovidas pelo jogo estético das imagens das paisagens devocionais marianas. Os cenários (interno/externo) da teatralidade urbana de santuários multiplicam o valor patrimonial das localidades em diversas tradições. 


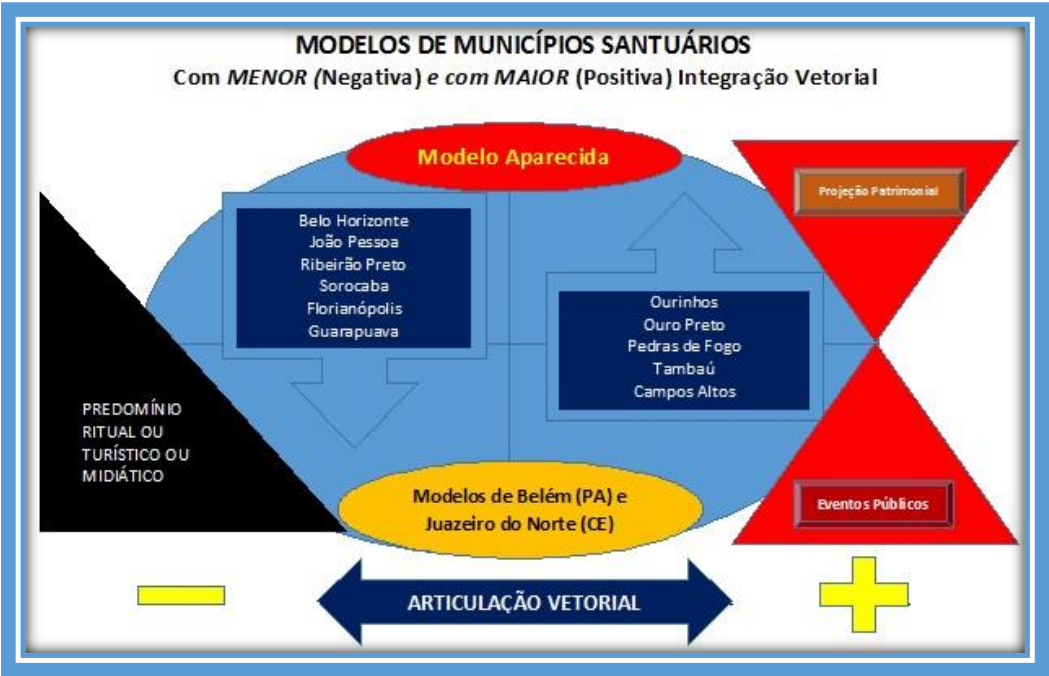

Figura 02: Esquema Gráfico mostrar a tipologia dos Municípios-Santuários Fonte: Elaboração do autor (2016).

Esses cenários, geograficamente atualizados na matergrafia do processo patrimonial, são núcleos de formação de uma rede de conexões muito complexa. Posto que ela se encontra, como veremos, já pronta (herdada), em tessitura (incompleta) e, ao mesmo tempo, em plena diluição com os signos da diversidade terrestre (sincretismo telúrica).

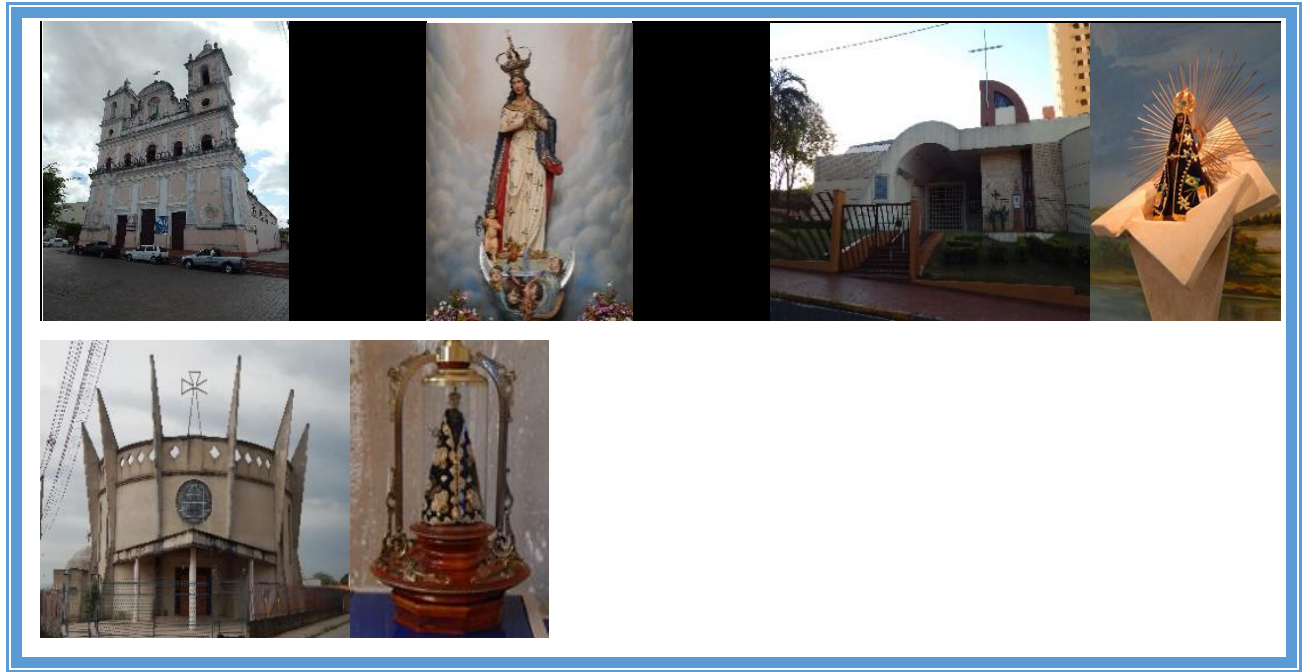

Figura 03: Santuários e Santas (Conceição Aparecida) diversificando a irradiação Fonte: Acervo do LEGES (2016). 


\section{1) Irradiação por inversão vetorial: desafios às Rede de Municípios-Santuários}

Passar dos modelos vetoriais, agregadores das forças de visitação, comunicação e ritualização, para um desenho de sistematicamente reverso é, aparentemente, "negar" o fenômeno simbólico da irradiação devocional em um só movimento: inversão. Mas as aparências, quando não enganam, demonstram a força dos modelos reflexivos; mesmo quando pesquisas de natureza qualitativa dirigem o processo de investigação. Em nosso caso, isso se instaura pela processual antinomia das doutrinas cristãs, que radicalizam o caminho teísta (divino) como único para a Salvação humana; ao mesmo tempo-espaço que promovem, incentivam, absorvem a corporeidade mariana como imagem indispensável da graça de Deus.

Pode-se recuperar o jogo das aparências na sutileza da interpretação profética do sociólogo Jean-Marie Guyau (1854-1888). Em seu tratado sobre as tendências pósmodernas da religião - A irreligião do futuro: estudo sociológico - trabalha, nos capítulos finais, as hipóteses metafísicas, ou em outras palavras, sistemas de valores racionalmente críveis e capazes de substituir os poderes irracionais ou ilusórios das devoções:

Depois dos estoicos e de Kant, produziu-se uma espécie de orientação de todas as hipóteses metafisicas. O que constitui hoje o maior atrativo dessas hipóteses é que elas tendem a dar sentido moral ao mundo, imprimir à evolução universal uma direção que esteja em conformidade com a da nossa consciência enquanto seres sociais e afetuosos. A história futura das religiões se resume na lei de que os dogmas religiosos, transformados primeiramente em simples conjecturas metafísicas e reduzidos mais tarde a um certo número de hipóteses entre as quais cada indivíduo fará uma escolha sempre mais racional, virão, enfim, voltar-se principalmente para o problema moral: a metafísica religiosa terminará por ser, sobretudo, uma moral transcendente, uma sociologia ideal abarcando todos os seres que constituem o universo. (GUYAU, [1886] 2014, p. 682)

A projeção-resposta de uma conduta "moral" para as transformações sociológicas da humanidade, sob o signo da modernidade, tende a ignorar a conjuntura explosiva das transformações geográficas emergentes no mundo ocidental nos últimos 150 anos. Por afinação científica de ofício, lemos o predomínio de outra conduta: a estética. Não apenas porque a irreligião panteísta de Guyau foi programada em uma trama insubordinada de religiões, filosofias, ciências e seitas; mas por especial orquestração daquilo que Gilles Lipovetsky e Jean Serroy denominam hipermodernidade, movida à base de estetização absoluta do capitalismo no século XXI. Os autores recompõem a tradicional percepção do espaço religioso na lógica extrovertida do espetáculo e do divertimento.

$\mathrm{Na}$ era do Capitalismo artista, hiperespetáculo, consumo e divertimento formam o sistema. $\mathrm{O}$ divertimento não é mais um domínio marginal e separado, ele se tornou um setor econômico fundamental, uma indústria transestética que cresce a cada dia. Hoje 
o universo do divertimento se estende bem além do cinema, da televisão e da música; ele engloba os objetos, os jogos, a informação, a comunicação, as cidades, os espaços comerciais, os museus, o patrimônio e até mesmo as comemorações nacionais. $\mathrm{O}$ divertimento não se opõe mais à economia nem à vida cotidiana; no reinado do capitalismo criativo; ele se infiltra em todos os espaços da vida e se fusiona com o mercado. Estamos na era do divertimento integrado e generalizado, marcado pela hibridação da mercadoria, da emoção e da distração de massa (LIPOVETSKY; SERROY, 2016, p. 270)

Gigantismo, choque visual, provocações sonoras e linguísticas, escalada de violência e culto às celebridades, povoam tanto os conceitos de análise do hiperespetáculo, quanto as formas de leitura simbólica da teatralidade dos Santuários Marianos. Exatamente pela somatória de forças teatrais - tempo/espaço/movimento - que Pavis (2008) denominou como "vetoriais", é que nos permitimos a ultrapassagem analítica para afirmar que a irradiação devocional se dá por inversão: enquanto mitos rituais, mídias publicitárias e migrações turísticas são emanadas da energia ético-religiosa do santuário, a compreensão devocional depende de uma emergência ou emanar da Estética. Sem uma beleza - e a da Virgem Maria, festiva e divertidamente, compatibiliza isso - a densidade da mensagem cristã já não se sustenta.

Nesses termos, quer ser pensar um contra vetor. Em outras palavras, um vetor invertido da poética como teatralidade do saber devocional. Aquilo que dá substância à concepção de sistema cultural e religioso, convertido em "geossímbolo" da territorialidade na ótica do geógrafo Joël Bonnemaison. Ao pesquisar o enraizamento "em êxodo" dos Judeus à expectativa de volta a Jerusalém (terrestre ou celeste), Bonnemaison indica na religião uma metáfora funcional da geografia como terra prometida. Conforme o relato de Claval (2003, p. 14),

Uma parte importante da identidade das sociedades não geográficas, no sentido de Joël Bonnemaison, encontra seus fundamentos nas religiões: trata-se desta vez de religiões reveladas, e não de politeísmos ou animismos, que localizam os seres e as forças divinas nas plantas, pedras ou seres. $\mathrm{Na}$ época moderna, as identidades aparecem cada vez mais dependentes das ideologias de progresso e das filosofias da história. O estudo dos sentimentos de identidade e de territorialidade aparece então fortemente vinculado ao das religiões.

Esses sentimentos geográficos que se projetam no imaginário religioso demandam eventos, celebrações, atos sagrados em tempos e espaços sacralizados pelo duplo sentido da encenação. O teatro da fé, que os santuários condensam, revela e esconde em duplicidade estética, o alerta genial de Artaud ([1935] 2006, p. 126-128) ao tratar a estética pulsante da linguagem teatral:

Considerado sob esse ângulo, o trabalho objetivo da encenação reassume uma espécie de dignidade intelectual através do 
desvanecimento das palavras por trás dos gestos e pelo fato de a parte plástica e estética do teatro abandonar seu caráter de interlúdio decorativo para tornar-se, no sentido próprio da palavra, uma linguagem diretamente comunicativa [...] Em suma, o teatro deve tornar-se uma espécie de demonstração experimental da identidade profunda entre o concreto e o abstrato.

O vetor invertido da estética festiva, nos espetáculos de louvação mariana são jogos de concretas idealizações espirituais e abstratas materialidades terrenas. Cenários eclesiais de arquiteturas estranhas (mas desejadas) acolhem no dentro/fora cenas de conciliação das múltiplas e irrequietas maneiras de criar o ser humano/divino (no vente ou no colo) da Mãe Terra. Assim como nas expressões em pares do Quadro 1, as imagens Marianas materializam a estética dos jogos teatrais, por inversão do cenário para cena. Seja na frequência "destrutiva" denunciada pelo radical consumismo de valores da "estetização do mundo hipermoderno" e majoritariamente excludente; seja na frequência "construtiva", geralmente inclusiva, no tocante à promoção de santuários festivos e integradores de eventos religiosos em uma rede geográfica de celebrações.

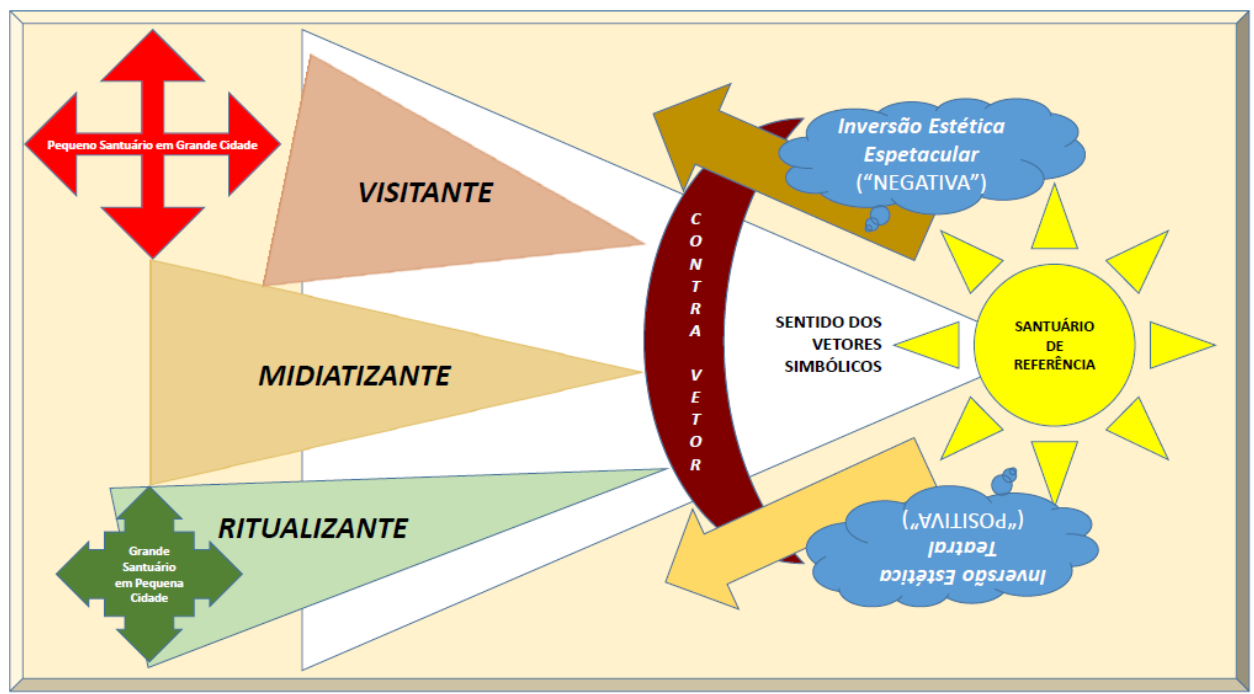

Figura 04: Esquemas 3X1 das Forças Vetoriais e seu contra vetor Fonte: Elaboração do autor (2017).

Exatamente por esse motivo, os municípios-santuários (nós dessa comunicação entrecortada) antecipam ou evocam uma rede continental de tensões/conciliações em escala. Projetam um Continente Santuário para forjar no espaço simbólico terrestre uma Matergrafia do patrimônio religioso. Os "palcos" municipais dos santuários comportamse como profecias cênicas de recepção dos sentidos das forças vetoriais (visitante, midiatizante e ritualizante) e contra vetoriais (de inversões estéticas, espetacular e teatral), 
conforme procuramos esquematizar na Figura 5. A ideia do esquema-síntese é operar uma atualização da Figura 4 para envolver (e readaptar) outros estudos semelhantes nas diferentes nacionalidades do continente; visando, assim, a ampliação da Rede espaçotempo que os santuários referenciais, suas projeções menores no interior e articulações maiores nas capitais e metrópoles, evocam.

\section{2) A Matergrafia na escrituração da Latinidade Continental}

A radicalização estética das formas patrimoniais, como força de reação ou resposta aos vetores simbólicos, conduzem a ampliação do nosso olhar mais definitivamente rumo a escala continental. Consideramos isso um exercício indutivo do trabalho de interpretação, uma hermenêutica dos santuários, em continuidade ao exercício epistemológico que iniciamos há 3 anos, na investigação das implicações entre os lugares representativos e seus santuários marianos. Indicamos daí duas epistemologias no processo de compreensão geográfica do Continente, tendo em vista sua latinidade como cultura comunicacional de unificação.

Pelo viés das tradições culturais materializadas em bens herdados, chamaremos a primeira de Matergrafia. Em complementação, considerando as novas conexões cibernéticas (ou bens projetados), vamos denominar a segunda pelo neologismo de Teopolifonia. As devoções preliminarmente situadas aqui, em tipos distintos de santuários latinoamericanos, tendem a formar, portanto, um conjunto de bens herdados e projetados como modelos geoeducacionais de comunicação. A matergrafia, trabalhada no item seguinte, conforma um modelo científico de aprendizagem do sistema terrestre por intermédio das imagens gráficas ou literárias, com base na imaginação criadora de Bachelard. A Terra é ensinada como Gaia; mas sua aprendizagem é herança de uma compreensão maternal. Em contrapartida, o segundo modelo epistemológico, teopolifonia, centrada no dialogismo de Bakhtin, corresponde a uma filosofia de ensino demandante de sensibilidade religiosa. Neste, a Terra é aprendida como Portal: do Reino de Deus, da Terra Sem Males, da África Mística ou do Nirvana, entre tantas possibilidades. Em qualquer dos casos, a compreensão é predominantemente paternal. OLIVEIRA; ARAÚJO; TAVARES, 2016, p. 55-56)

Manuseando essas tipologias do simbolismo materno e paterno - como parâmetros de aprendizagem (casa de acolhimento) e ensino (portal de viagem) - tanto a Imaginação de Bachelard e quanto o Dialogismo de Bakhtin nos permitem a extrapolação da leitura dos santuários marianos brasileiros em outros 20 modelos congêneres, espelhados por países do continente Americano, onde o catolicismo, com maior ou menor força, forja um espaço patrimonial. A matergrafia e a teopolifonia, respectivamente, condicionam e projetam o fluxo dos valores patrimoniais que a inversão vetorial faz emergir. Principalmente quando se trata de reconhecer no planejamento dos lugares a impossibilidade de um investimento na demarcação de uma cultura latino-americana, com 
abrangência macro continental, sem a participação dos lugares santuários nas formas de representação (SÁ, 1996) regional e nacional. Seja para caracterizar a resistência das sociedades cubana e venezuelana, aos socialismos; seja para demonstrar a complexidade multicultural canadense ou norte-americana; ou mesmo para expor a mercantilização das emergentes economias argentina, chilena e brasileira há que se ler os municípios-santuário de escala nacional como conectores de uma ideologia religiosa, cristã e ocidental: A América é Latina também porque permanece desenhada nos princípios devocionais marianos. E para além das amarras católicas dessa origem e gestão, a dimensão patrimonial da latinidade não pode ignorar tal geografia.

A seleção que caracteriza o Quadro 2 foi estabelecida em função da permanência de uma representatividade e/ou herança dos "estados católicos" (incluindo o catolicismo anglicano) demarcadores das repúblicas do Extremo Ocidente. A lista não contempla todos os 35 países independentes, pois privilegiou o acesso a um site ou blog que permitisse ao leitor informações relativamente atualizadas do sistema devocional mariano mais reconhecimento (nacionalmente) com a titularidade de "padroeira" nacional.

Uma visita às origens oficiais, processos históricos e efeitos publicitários das imagens marianas nacionais, aponta para a necessidade de um universo de especificidades no contexto de cada nacionalidade. Não se trata aqui de fazer o detalhamento do quanto diversas virgens de invocação semelhantes - como no exemplo da invocação à Conceição na Argentina, Paraguai, Nicarágua e EUA - projetam especificidades locais e modulam equivalências de autonomia regional/nacional, multiplicando a devoção de Aparecida. Afinal, mesmo quando a mexicana Virgem de Guadalupe renova o mito de origem da Guadalupe espanhola, em outra nacionalidade, nada impede que se leia em exclusividade e a projete em enfoque continental.

Quadro 03: Devoções nacionais com informações razoavelmente disponibilizadas.

\begin{tabular}{|c|c|c|c|}
\hline $\begin{array}{l}\text { SANTUÁRIO DA } \\
\text { PADROEIRA }\end{array}$ & \multicolumn{2}{|c|}{$\begin{array}{l}21 \text { MUNICÍPIOS E NACÕES } \\
\text { DAS } 3 \text { AMÉRICAS }\end{array}$} & $\begin{array}{l}\text { ENDEREÇO VIRTUAL DE } \\
\text { SANTUÁRIOS }\end{array}$ \\
\hline Santuário/Devoção & Município & País & $\begin{array}{l}\text { Site/Blog com informações } \\
\text { diversificadas }\end{array}$ \\
\hline N. Sra. de C. de Lujan & Lujan & ARGENTINA & http://www.basilicadelujan.org.ar/ \\
\hline N. Sr.a. de Copacabana & Copacabana & BOLÍVIA & $\begin{array}{l}\text { http://forosdelavirgen.org/193/nu } \\
\text { estra-senora-de-la-candelaria-de- } \\
\text { copacabana-bolivia-5-de-agosto/ }\end{array}$ \\
\hline $\begin{array}{l}\text { N. Sr.a. da C. } \\
\text { Aparecida }\end{array}$ & Aparecida (SP) & BRASIL & http://www \\
\hline N. Sr.a. do Rosário & Cap Madalaine & CANADÁ & https://www.sanctuaire-ndc.ca/en \\
\hline N. Sr.a. del Carmem & San & CHI & $\begin{array}{l}\text { http://www.virgendelcarmen.cl/v } \\
\text { dc-en-la-historia-de-chile.php }\end{array}$ \\
\hline N. Sr.a. del Rosário & Chiquinquirá & COLÔMBIA & http://virgendechiquinquira.com/ \\
\hline N. Sr.a. de Los Angeles & Cartago & COSTA RICA & $\begin{array}{l}\text { http://forosdelavirgen.org/188/nu } \\
\text { estra-senora-de-los-angeles-costa- } \\
\text { rica-2-de-agosto/ }\end{array}$ \\
\hline N. Sr.a. da Caridade & El Cobre & CUBA & $\begin{array}{l}\text { https://www.ecured.cu/Santuario_ } \\
\text { de_Nuestra_Se\%C3\%B1 ora_de_1 } \\
\text { a_Virgen_de_la_Caridad_del_Co } \\
\text { bre }\end{array}$ \\
\hline
\end{tabular}




\begin{tabular}{|c|c|c|c|}
\hline $\begin{array}{l}\text { SANTUÁRIO DA } \\
\text { PADROEIRA }\end{array}$ & \multicolumn{2}{|c|}{$\begin{array}{l}21 \text { MUNICÍPIOS E NACÕES } \\
\text { DAS } 3 \text { AMÉRICAS }\end{array}$} & $\begin{array}{l}\text { ENDEREÇO VIRTUAL DE } \\
\text { SANTUÁRIOS }\end{array}$ \\
\hline N. Sr.a. da Paz & San Miguel & $\begin{array}{c}\text { EL } \\
\text { SALVADOR }\end{array}$ & $\begin{array}{c}\text { http://www.reinadelcielo.org/nues } \\
\text { tra-senora-de-la-paz-patrona-de- } \\
\text { el-salvador/ }\end{array}$ \\
\hline N. Sr.a. del Quinche & Quito & EQUADOR & $\begin{array}{c}\text { http://forosdelavirgen.org/395/nu } \\
\text { estra-senora-de-la-presentacion- } \\
\text { del-quinche-ecuador-21-de- } \\
\text { noviembre/ }\end{array}$ \\
\hline N. Sr.a. da Conceição & Washington & EUA & $\begin{array}{l}\text { http://www.nationalshrine.com/sit } \\
\text { e/c.osJRKVPBJnH/b.4719297/k. } \\
\text { BF65/Home.htm }\end{array}$ \\
\hline N. Sr.a. do Rosário & Guatemala & GUATEMALA & $\begin{array}{l}\text { http://forosdelavirgen.org/327/nu } \\
\text { estra-senora-del-rosario- } \\
\text { guatemala-7-de-octubre/ }\end{array}$ \\
\hline N. Sr.a. de Concepción & Suyapa & HONDURAS & $\begin{array}{l}\text { http://forosdelavirgen.org/529/nu } \\
\text { estra-senora-de-la-concepcion-de- } \\
\text { suyapa-honduras-3-de-febrero/ }\end{array}$ \\
\hline N. Sr.a. de Guadalupe & México & MÉXICO & $\begin{array}{c}\text { http://basilica.mxv.mx/web1/- } \\
\text { home/index.html }\end{array}$ \\
\hline N. Sr.a. de Concepción & El Viejo & NICARÁGUA & $\begin{array}{l}\text { http://www.corazones.org/maria/a } \\
\text { merica/nica_inmaculada_viejo.ht } \\
\text { m }\end{array}$ \\
\hline N. Sr.a. de La Antigua & Panamá City & PANAMÁ & $\begin{array}{l}\text { http://forosdelavirgen.org/266/san } \\
\text { ta-maria-la-antigua-panama-9-de- } \\
\text { septiembre/ }\end{array}$ \\
\hline N. Sr.a. de Caacupé & Caacupé & PARAGUAI & $\begin{array}{c}\text { http://forosdelavirgen.org/415/nu } \\
\text { estra-senora-de-los-milagros-de- } \\
\text { caacupe-paraguay-8-de- } \\
\text { diciembre/ }\end{array}$ \\
\hline N. Sr. a. das Mercês & Lima & PERU & $\begin{array}{l}\text { http://forosdelavirgen.org/286/nu } \\
\text { estra-senora-de-la-merced-peru- } \\
\text { 24-de-septiembre/ }\end{array}$ \\
\hline N. Sr.a. de Altagracia & Higuey & $\begin{array}{l}\text { REPÚBLICA } \\
\text { D. } \\
\end{array}$ & $\begin{array}{c}\text { http://www.basilicahiguey.com/in } \\
\text { dex.php }\end{array}$ \\
\hline N. Sr.a. de los 33 & Montevideo & URUGUAI & $\begin{array}{l}\text { http://forosdelavirgen.org/376/vir } \\
\text { gen-de-los-treinta-y-tres-uruguay- } \\
\text { 8-de-noviembre/ }\end{array}$ \\
\hline N. Sr.a. de Coromoto & Guanare & VENEZUELA & $\begin{array}{l}\text { http://www.santuariobasilicacoro } \\
\text { moto.com/SNCoromotoWeb/hist } \\
\text { ory1 }\end{array}$ \\
\hline
\end{tabular}

Fonte: Elaboração do autor (2017).

Sendo Guadalupe a padroeira da América Latina, considerando o peso cosmopolita do município-santuário (a própria capital mexicana e do império asteca), pode-se apontar a expressividade reticular de linhas de interpretativas para cada panorama devocional. Até que ponto, pescas "milagrosas", incidentes com "imagens", eventos históricos libertários, visões e celebrações de episódios "épicos" ou "trágicos", imprimem - tal qual o manto do Santo Indígena Juanito" (visionário de Nossa Senhora) - uma narrativa teopolifônica (didática) para a mesma compreensão matergráfica (em 
aprendizagem significativa)? Talvez, conforme os estudos nos revelam até aqui, é impossível tratar as aparições de marianas apenas como atrativo turístico religioso dos nós górdios que embaraçam cristianismo/paganismos, ao longo dos caminhos que santificaram a personagem Maria, mãe de Jesus (ALVARES, 2015; STEIL; MARIZ; REENSINK, 2003). O mais plausível seria responder à pergunta do até que ponto, multiplicando pontos e tecendo a continentalidade latina, na capacidade de reinterpretar agentes e elementos identificadores das forças 3X1, compostas a partir do Quadro 2, exposto anteriormente. O desafio para os trabalhos na longa lista de países latino-americanos está agora disponibilizado.

\section{Concluindo: riscos fundamentalistas de matricídio no patrimônio religioso}

O percurso percorrido por esse sinuoso artigo estaria comprometido com a interpretação da rede geográfica que nomeamos por Matergrafia do Patrimônio Religioso se não deixássemos emergir os problemas do transbordamento do catolicismo mariano simbólico em catolicismo político-ideológico. O contexto contemporâneo, de exacerbação dos direitos à diversidade e pluralismo religioso, sinaliza avanços na capacidade social de se "fazer a coisa certa" como um parâmetro de responsabilidade moral. Isso levando em consideração os alertas equitativos delimitados por Sandel (2016, p. 277), quando inclui a importância das obrigações de solidariedade entre os deveres naturais e as questões individuais e voluntárias.

Diferentemente dos deveres naturais, as obrigações de solidariedade são particulares, e não universais; elas envolvem reponsabilidades morais que devemos ter não apenas com os seres racionais, mas com aqueles que compartilhamos uma determinada história. No entanto, diferentemente das obrigações voluntárias, elas não dependem de um ato de consentimento. Seu valor moral fundamenta-se, ao contrário, no aspecto localizado da reflexão moral, no reconhecimento do fato de que minha história de vida está implicada na história dos demais indivíduos.

É justamente o caminho intermediário das obrigações de solidariedade, readaptado para os planos de duplicidade - matricial, no que concerne a origem do cristianismo e teatral, no jogo estético da inversão de vetores simbólicos - que se vê obstruído quando se reivindica a experiência dos santuários marianos como nucleação do patrimônio cultural latino-americano. Embora os inventários de tombamento (material) e salvaguarda (imaterial) recomendados pelo Instituto Brasileiro de Patrimônio Histórico e Artístico Nacional (IPHAN), no Brasil, siga padrões da UNESCO no tocante aos cuidados de promoção da diversidade social, mantém-se uma arriscada resistência, cujo conflito leva a dois modelos do que aqui denominamos matricídio. De um lado, há o rompante teológico e mercadológico, no enfrentamento da hegemonia católica, capaz de erguer a devoção à Nossa Senhora como crivo radical de identidade católica. O que se traduz nos exageros da estética espetacular do culto à Virgem, destituída de seu papel de mediadora 
do alcance devocional à Santíssima Trindade, para assumir a vanguarda da aceitação de que "Catolicismo Apostólico Romano", que em si seria uma religião com práticas distintas de outros catolicismo, protestantismo e evangelismos, ignorantes ou desconfiados do poder dogmático de Maria. Para lembrar que essa força das devoções marianas dinamizam uma ação estratégica de manutenção da hegemonia católica nos lugares, sem espaço para negociações, Aquino (2011) apresenta todo um desenho de como a patrimonialização do santuário diocesano incorporou ícones e figurações aos emblemas institucionais do município de ourinhos para comemorar em 2004 os 50 anos de sua mariofania (expressão do autor). A imagem foi intacta de Aparecida foi resgatada de um vagão de trem, em um incêndio ocorrido em julho de 1954. Eventos, celebrações e grandes festivais dos cultos marianos - como o próprio Ano Mariano de 2017 para marcar o Jubileu dos 300 anos do achado da imagem de Conceição Aparecida, em São Paulo (Brasil, 1717) e dos 100 anos da aparição de da Virgem do Rosário de Fátima (Portugal, 1917). Tais celebrações, sem explicitar formar de inclusão ecumênica e mecanismos de tolerância e participação efetiva de outras de outras tradições religiosas, abrem espaço para posturas reversas.

De outro lado, poderia ser reconhecido como uma recusa ou fuga do marianismo - uma marianofobia, talvez - cujo efeito imediato é a acusação de heresia, de outros cristãos aos católicos, por divinizarem ou endeusarem uma mulher como Mãe de Deus. Ao mesmo tempo em que toda facilidade sincrética da figura mariana desenha vínculos de simultaneidade religiosa. Afinal, um marianismo aberto à interpretação da moral solidária, essa que move a tessitura cosmopolita das cidades, metrópoles e comunidades ocidentais, permite a um cristão republicano práticas islâmicas, hinduístas, budistas, xamânicas, animistas, indígenas, umbandistas, entre tantas, desde que movidas pela piedade ativa da acolhida humanista. Em certa medida, é essa amplitude de práticas maternais contemporâneas que repele os representantes mais fundamentalistas de outros sistemas. É ela também que ajuda a negociação intercontinental das diversas crises de refugiados no planeta. Tal tessitura, mesmo nas contradições, aglutina a grande massa social de descendentes indígenas e africanos, praticantes de cultos forjados na composição teatral das tribos, quilombos e terreiros, geralmente às margens dos centros elitizados, encontram nos santuários marianos da América Latina, micros ou macros condições especiais de manifestação e desafio sociocultural.

O conjunto de festividades, que giram em torno das homenagens dos Povos de Tradição às Mãe da Nacionalidade nos países do continente é alvo fácil de um matricídio geográfico. Ato fundamentalista que poda, quando não mata literalmente, os elementos mais representativos dos princípios de Laicidade como sustentáculos da ligação entres a Geografia dos Símbolos Marianos ou Matergrafia e Espaço/Tempo de Valorização da Culturas ou Patrimônio.

Cientes de que esse estudo, aqui parcialmente encerrado, ainda precisa contemplar etapas de comparações efetivas das devoções marianas com outras celebrações (Cristãs e não Cristãs) no continente, consideramos oportuna a ideia de reforçar alguns pontos tratados, sem os quais a espaço reticular dos municípios santuários não se fortaleceria. 
1) A MATERGRAFIA pode continuar sendo um instrumental de análise da aprendizagem simbólica dos sistemas culturais religiosos, desde que não se restrinja a pensar a Devoção mariana do Catolicismo como modelo único ou padrão de reverência à Terra, à Natureza e às forças espirituais que as promove. Apesar de todo esforço para compreensão dos santuários de Conceição Aparecida, em nenhum momento se teve a intenção de restringir a concepção de Matergrafia ao modelo católico de culto à Senhora da Conceição. Cientificamente, o segundo é apenas um exemplo possível para a complexidade do primeiro. E como foi visto, nos fornece grandes possibilidade de interpretação geográfica;

2) O PATRIMÔNIO - em seu recorte cultural, religioso e predominantemente imaterial - deve permanecer um campo de debate identitário e uma crescente fonte de aproximação da Geografia das linguagens artísticas (teatrais especialmente). Daí tematicamente o considerarmos um combustível temático impar para impulsão das forças vetoriais simbólicas, sem as quais a análise dos relacional dos espaços marianos (internos ou externos) aos circuitos eclesiais

3) Os MUNICÍPIOS-SANTUÁRIOS correspondem aos lugares-símbolo de uma insuperável fusão (e confusão) de poderes políticos (seculares e eclesiais), cuja tendência é imitar, no jogo de tempo e espaço comunicacional (cronotopia) os grandes santuários marianos do continente latino-americano. Sua complexidade e fartura de tensões espaciais alcanças com especificidades formais diferentes escalas, obrigando uma Geografia das Comunicações a pensar sistematicamente a categoria Rede Espaço-Temporal para os movimentos religiosos nos espaços de maior densidade técnica: Capitais estaduais (no Brasil) e nacionais (no continente americano).

Projeta-se o estudo das Festas-Capitais em continuidade aos vínculos entre Matergrafia e Patrimônio, destacando os Municípios-Santuários com maior representatividade regional oficial. E aglutina-se o desafio profano e secular de pensar suas especificidades organizacionais e sua convivência com outras celebrações, cristãs e não cristãs. São nessas direções que o vento da discussão bachelardiana, sobre o "estudar" fundante, nos levam de agora em diante.

\section{Agradecimentos especiais}

Ao Conselho Nacional de Desenvolvimento Científico e Tecnológico (CNPq), que financiou a bolsa de pesquisa produtividade e o Projeto do Edital Universal, aprovado em 2014 (Chamada Universal - MCTI/CNPq - 14/2013), com o título Estratégias da Irradiação Devocional Mariana: Formação de Banco de Dados e Imagens na Tipologia de Municípios-Santuário como subsídio à Política de Patrimônio Religioso. À Coordenadoria de Aperfeiçoamento de Pessoal do Ensino Superior (CAPES) que estímulou o vínculo direto deste trabalho com o Programa de Pós-Graduação em 
Geografia da Universidade Federal do Ceará (UFC). À UFC e ao Sindicato das Universidades Federais do Estado do Ceará (ADUFC), que me proporcionaram condições para apresentar o trabalho no $34^{\circ}$ Conferência de Geógrafos Latino-americanistas (CLAG) em Nova Orleans (EUA).

\section{Referências}

ALVAREZ, R. Maria: A biografia da mulher que gerou o homem mais importante da história, viveu um inferno, dividiu os cristãos, conquistou meio mundo é chamada Mãe de Deus. São Paulo: Globo, 2015.

AQUINO, M. História e devoção: a construção social do culto a Nossa Senhora Aparecida do Vagão Queimado de Ourinhos-SP (1954-2004). Bauru-SP: EDUSC, 2011. ARTAUD, A. M. J. O teatro e seu duplo. SP: Martins Editora, 2006.

BACHELARD, G. Estudos. São Paulo: Contraponto Editora, 2008 [1934].

CERTEAU, M. de. A invenção do cotidiano: 1; Artes de fazer. Petrópolis: Vozes, 1990.

CLAVAL, P. Religion et idelologie: perspectives geographiques. Paris: Press de l’Université Paris-Sorbonne, 2008.

CLAVAL, P. A evolução recente da geografia de língua francesa. Geosul, v.18, n. 35, 2003. Disponível em:

<https://periodicos.ufsc.br/index.php/geosul/article/viewFile/13599/12466>. Acesso em: 25 fev. 2017.

FERRARA, L. D’A. Comunicação, espaço e cultura. São Paulo: Annablum, 2008.

GIL FILHO, S. F. Espaço sagrado, estudos em Geografia da Religião. Curitiba, IBPEX, 2008.

GUYAU, J. M. A irreligião do futuro: estudo sociológico. São Paulo: Martins Fontes, 2014 [1886].

KOZEL, S. Um panorama sobre as geografias marginais no Brasil. (p. 12/27) In: HEIDRICH. A. L.; COSTA B. P da.; PIRES, C. L. Z. Maneiras de ler geografia e cultura. Porto Alegre: Imprensa Livre; Compasso Lugar Cultura, 2013. p. 12-27. Disponível em: <https://laboter.iesa.ufg.br/up/214/o/ MANEIRAS_DE_LER_GEOGRAFIA_E_CULTURAL.pdf >. Acesso em: $25 \mathrm{fev}$. 2017.

LIPOVETSKY, G.; SERROY, J. A estetização do mundo, viver na era do capitalismo artista. São Paulo: Companhia das Letras, 2015.

OLIVEIRA, C. D.M. de. Basílica de Aparecida: um templo para a cidade-mãe. São Paulo: Olho D'água, 2001. 
OLIVEIRA, C. D.M. de. Turismo religioso. São Paulo: Aleph, 2004.

OLIVEIRA, C. D.M. de. Caminhos da festa ao patrimônio geoeducacional: como educar sem encenar Geografia? Fortaleza: Editora da UFC, 2012.

OLIVEIRA, C.; ARAÚJO, J.; TAVARES, K. Patrimônio Geoeducacional na formação simbólica de municípios-santuários na América do Sul. GEOSABERES: Revista de Estudos Geoeducacionais, América do Norte, V.6 2022016.

PAVIS, P. Análise dos espetáculos: teatro, mímica, dança, dança-teatro, cinema. São Paulo: Perspectiva, 2008.

RUIZ, C. B. Os paradoxos do imaginário. São Leopoldo: Ed. Unisinos. 2004.

SÁ, C. P. de. Núcleo central das representações sociais. Petrópolis: Ed. Vozes, 1996.

SANDEL, M. J. Justiça: o que é fazer a coisa certa? Rio de Janeiro: Civilização Brasileira, 2016.

SANCHEZ, W. L. Pluralismo religioso: as religiões no mundo atual. São Paulo: Paulinas, 2010.

SANTOS, M. da G. M. P. Espiritualidade, turismo e território: estudo geográfico de Fátima. Estoril: Principia, 2006.

SANTOS, B. S. Se Deus fosse um ativista dos Direitos Humanos. São Paulo: Cortez, 2014.

STEIL, C. A.; MARIZ, C. L.; REENSINK, M. L. Maria entre os vivos: reflexões teóricas sobre as aparições marianas no Brasil. Porto Alegre: Editora da UFRGS, 2003.

Christian Dennys Monteiro de Oliveira

Pós-doutor em Turismo pela Univeridade de São Paulo e em Geografia pela Universidade de Sevilla, Espanha. Doutor e mestre em Geografia Humana pela Faculdade de Filosofia, Letras e Ciências Humanas da Universidade de São Paulo. Bacharel e licenciado em Geografia pela Universidade de São Paulo. Atualmente é professor associado III da Universidade Federal do Ceará, onde também atua no Programa de de Pós-Graduação em Geografia.

Rua Moreira de Sousa, 525-306, Bairro Parquelândia - Fortaleza/CE. CEP: 60450080.

E-mail: cdennys@gmail.com 